\title{
Air Monitoring: New Advances in Sampling and Detection
}

\author{
Nicola Watson, Stephen Davies, and David Wevill \\ Markes International, Gwaun Elai Medi Science Campus, Llantrisant CF72 8XL, UK
}

Received 22 October 2011; Accepted 22 December 2011

Academic Editor: Richard Brown

As the harmful effects of low-level exposure to hazardous organic air pollutants become more evident, there is constant pressure to improve the detection limits of indoor and ambient air monitoring methods, for example, by collecting larger air volumes and by optimising the sensitivity of the analytical detector. However, at the other end of the scale, rapid industrialisation in the developing world and growing pressure to reclaim derelict industrial land for house building is driving the need for air monitoring methods that can reliably accommodate very-highconcentration samples in potentially aggressive matrices. This paper investigates the potential of a combination of two powerful gas chromatography-based analytical enhancementssample preconcentration/thermal desorption and time-of-flight mass spectrometry-to improve quantitative and qualitative measurement of very-low-(ppt) level organic chemicals, even in the most complex air samples. It also describes new, practical monitoring options for addressing equally challenging high-concentration industrial samples.

KEYWORDS: air sampling, air pollutants, mass spectrometry, volatile organic chemicals 


\section{INTRODUCTION}

Samples of vapour-phase volatile organic chemicals (VOCs) in ambient air are collected in a number of different ways, of which sorbent tubes, canisters, and bags are the most popular [1,2]. The representative sample of pollutants that results is then typically analysed by GC-MS.

However, in order to transfer a sample to the GC-MS without injecting large volumes of gas, a preconcentration device is needed. Ideally, the concentration device should allow selective retention of target VOCs while potential interferences such as water and $\mathrm{CO}_{2}$ are purged to vent. The state-of-the-art pre-concentration devices (focusing traps) built into modern thermal desorbers (TDs) are electrically cooled and configured such that retained analytes are desorbed/injected into the GC-MS with carrier gas flowing in the reverse direction to that used during the trapping/concentration process. Such "backflush" desorption means that the focusing trap can be packed with multiple sorbents in series, allowing a wider range of analytes to be sampled simultaneously (Figures 1 and 2).

The choice of air sampling method depends on the volatility and polarity range of the VOCs of interest $[1,2]$ and also varies from country to country, primarily because of historical investment. The USA, China and Japan, for example, have traditionally preferred canisters for time-weighted monitoring or grab sampling of the lighter VOCs [3-5], whereas methods across Europe and the rest of Asia have more typically favoured active or passive sampling using sorbent tubes [6-8].

Online/real-time air monitoring is also used extensively for kinetic studies and for compliance with specific regulations that require real-time monitoring data-for example, $\mathrm{C}_{2}$ to $\mathrm{C}_{10}$ hydrocarbon ozone precursors [9], odorous sulfur compounds [10,11], and some trace perfluorinated compounds which are now known to be potent and long-lived greenhouse gases [12].

Each air sampling/monitoring technique has its inherent advantages and disadvantages, and these have been explored in detail in previous work $[1,2]$.

\section{NEW ADVANCES FOR AIR SAMPLING USING CONTAINERS SUCH AS CANISTERS}

\subsection{High-Level Samples}

Small canisters (around $400 \mathrm{~mL}$ volume) have been growing in popularity for grab-sampling highconcentration volatiles (with vapour pressures greater than those of n-nonane). Pre-concentration/trapping is still required prior to analysis in order to selectively eliminate the bulk constituents of air, especially oxygen, which would otherwise adversely affect the performance of the GC column and detector. However, sample volumes must be minimised to prevent overloading and/or contaminating the analytical system. Care is also required for small volumes of air to be quantitatively transferred without introducing uncertainty, and this is usually achieved using gas sample loops, capable of accurately metering sample volumes in the order of a few hundred microlitres.

A recent development has enabled gas loop introduction to be combined with the latest TD trapping technology, postdesorption sample splitting and enhanced line purging, such that high-concentration samples can be automatically processed without compromising measurement accuracy and with sufficiently low carryover to enable much lower-level samples to be reliably measured on the same analytical system (Figure 3). Incorporating these techniques into a single system setup allows flexibility in the analysis of unknown concentration samples with the added capability of running trace and high-concentration samples in the same analytical sequence without compromising results. Prior to this development, samples would have to be prescreened on a separate system and once assessed dilution of high-concentration samples using a diluent gas would have to be carried out $[3,13]$, this was a time consuming and labour intensive setup, and by diluting the samples errors and more importantly the reporting limits will be elevated [13]. 


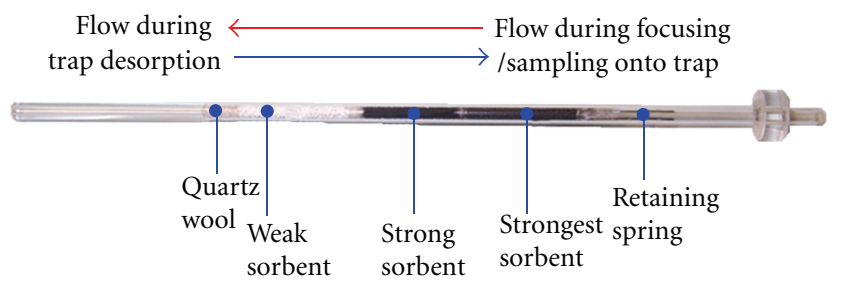

FIGURE 1: Multibed focusing trap (Markes International Ltd, UK), showing weak sorbents at the left for trapping semivolatile organic compounds and strong sorbents at the right for trapping very volatile organic compounds.

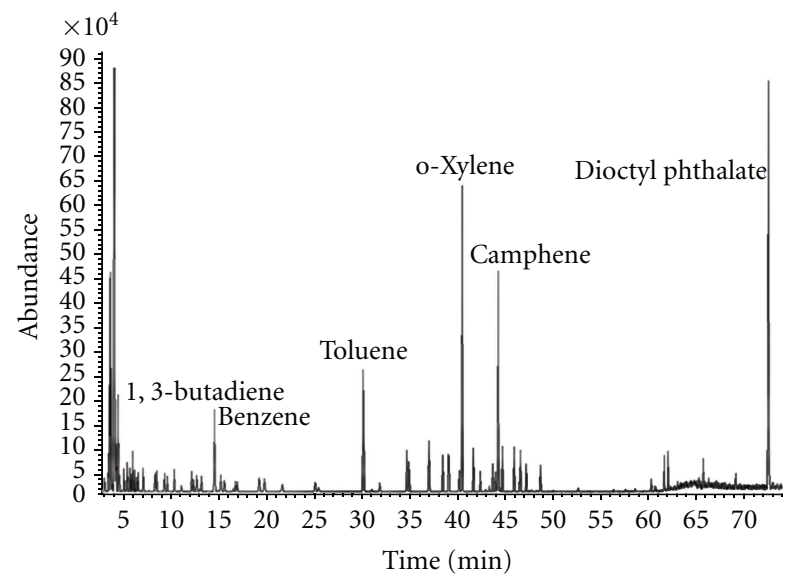

FIGURE 2: Tube desorption (TD-100, Markes International Ltd) demonstrating simultaneous analysis of a wide range of compounds relevant to materials emissions testing (method conditions are shown in Table 1).

TABLE 1: Sampling and analytical conditions.

\begin{tabular}{|c|c|c|}
\hline TD conditions & GC conditions & MS conditions \\
\hline $\begin{array}{l}\text { Configuration: TD- } 100 \text { for } \\
\text { automated tube desorption } \\
\text { (Markes International Ltd) } \\
\text { Flow path temperature: } 200^{\circ} \mathrm{C} \\
\text { Focusing trap: air toxics } \\
\text { analyser type trap } \\
\text { Trapping temperature: } 25^{\circ} \mathrm{C} \\
\text { Cold trap desorption: } 320^{\circ} \mathrm{C} \text { for } \\
10 \text { min }(20: 1 \text { split) } \\
\text { Trap heating rate: } 40^{\circ} \mathrm{C} / \mathrm{s}\end{array}$ & $\begin{array}{l}\text { Column: } 60 \mathrm{~m} \times 0.32 \mathrm{~mm} \times 1.0 \mu \mathrm{m} \text {, } \\
100 \% \text { dimethylpolysiloxane } \\
\text { Oven: } 35^{\circ} \mathrm{C}(25 \mathrm{~min}), 5^{\circ} \mathrm{C} / \mathrm{min} \text { to } 180^{\circ} \mathrm{C} \text {, } \\
\text { then } 15^{\circ} \mathrm{C} / \mathrm{min} \text { to } 320^{\circ} \mathrm{C}(12 \mathrm{~min}) \\
\text { Constant pressure: } 10 \mathrm{psi}\end{array}$ & $\begin{array}{l}\text { Source temperature: } 230^{\circ} \mathrm{C} \\
\text { Quadrupole temperature: } 150^{\circ} \mathrm{C} \\
\text { Transfer line temperature: } 280^{\circ} \mathrm{C} \\
\text { Scan range: } \mathrm{m} / \mathrm{z} 10-400\end{array}$ \\
\hline
\end{tabular}

Sampling: $1 \mu \mathrm{L}$ of a $100 \mathrm{ng} / \mu \mathrm{L}$ standard loaded onto a multi-bed sorbent tube (Tenax TA, Carbograph 1TD, Carboxen 1003).

Linearity tests were also carried out to evaluate this novel approach for analysing concentrated canister air against more conventional TD analysis procedures for lower-level (ambient) air samples (Figure 4).

The excellent linearity obtained across this range of air sample volumes, despite using two different approaches to metering the volume introduced to the focusing trap, shows good correlation of the data from samples introduced via gas sample loop and those metered using mass flow control. It is also noteworthy 


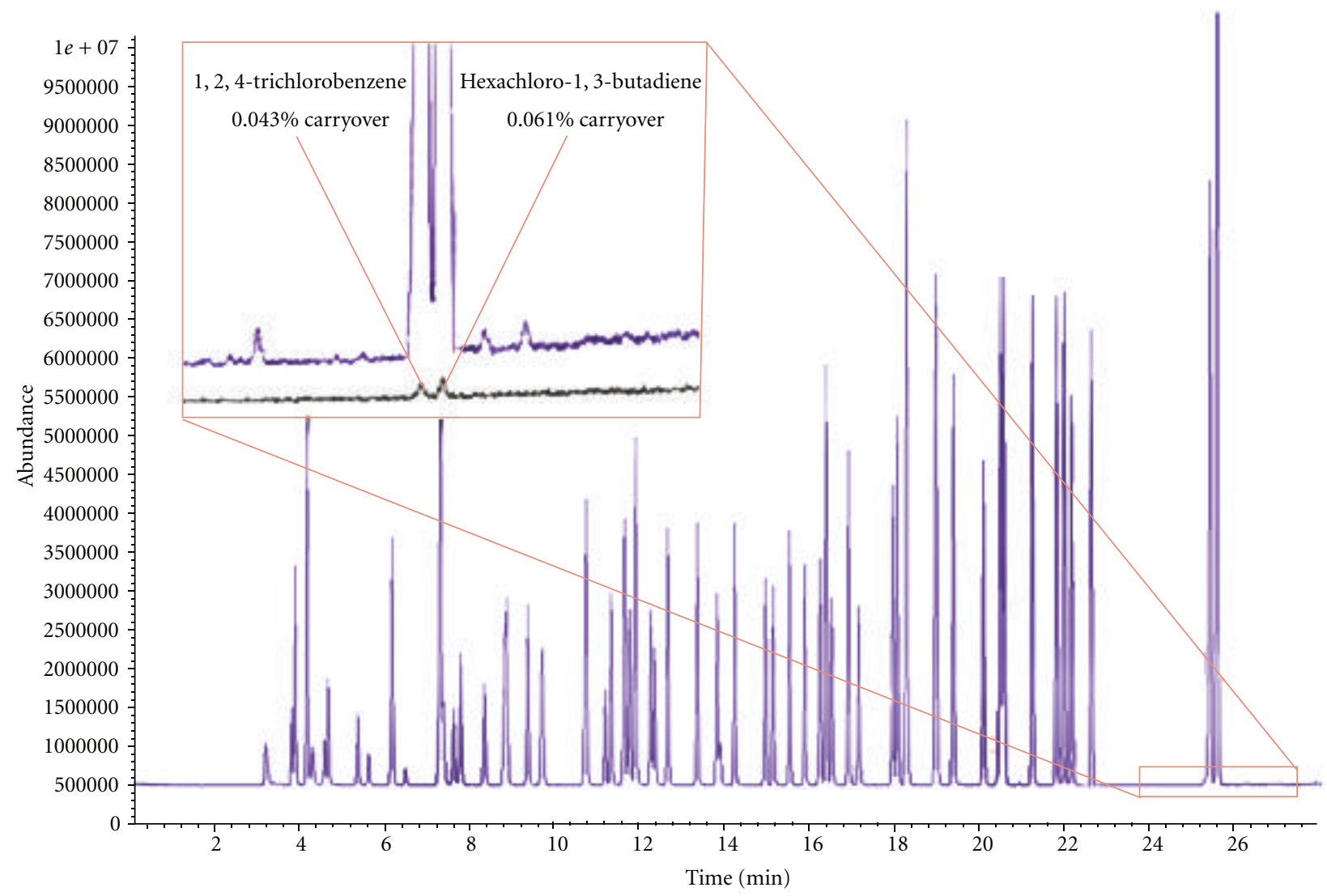

FIGURE 3: Main image: analysis of $40 \mathrm{~mL}$ of a $1 \mathrm{ppm}$ 62-component "US EPA TO-15 air toxics" standard (i.e., a heavily overloaded sample) using a CIA-Advantage system, (Markes International Ltd). Inset: Expansion of the peaks for 1,2,4-trichlorobenzene and hexachloro-1,3-butadiene, showing subsequent analysis of a $500 \mathrm{~mL}$ nitrogen blank demonstrating very low carryover even under extreme conditions and for these late-eluting components (method conditions are shown in Table 2).

TABLE 2: Analytical conditions.

\begin{tabular}{lll}
\hline TD conditions & GC conditions & MS conditions \\
\hline $\begin{array}{l}\text { Configuration: CIA-Advantage } \\
\text { automated canister analysis system } \\
\text { (Markes International Ltd) }\end{array}$ & & \\
$\begin{array}{l}\text { Sampling: } 40 \mathrm{~mL} / \mathrm{min} \text { for } 1 \mathrm{~min} \\
\text { (standard); } 50 \mathrm{~mL} / \mathrm{min} \text { for } 10 \mathrm{~min}\end{array}$ & Column: $60 \mathrm{~m} \times 0.32 \mathrm{~mm} \times 1.8 \mu \mathrm{m}$, & \\
(blank) & 624 type phase & Source temperature: $230^{\circ} \mathrm{C}$ \\
Flow path temperature: $150^{\circ} \mathrm{C}$ & $\mathrm{Oven}^{\circ} 40^{\circ} \mathrm{C}(5 \mathrm{~min}), 10^{\circ} \mathrm{C} / \mathrm{min}$ to & Quadrupole temperature: $150^{\circ} \mathrm{C}$ \\
$\begin{array}{l}\text { Focusing trap: air toxics analyser } \\
\text { type trap }\end{array}$ & $260^{\circ} \mathrm{C}(8 \mathrm{~min})$ & Transfer line temperature: $280^{\circ} \mathrm{C}$ \\
Trapping temperature: $25^{\circ} \mathrm{C}$ & Constant pressure: $10 \mathrm{psi}$ & Scan range: $\mathrm{m} / \mathrm{z} 35-300$ \\
$\begin{array}{l}\text { Cold trap desorption: } 320^{\circ} \mathrm{C} \text { for } \\
\text { 3 min }(5: 1 \text { split) }\end{array}$ & \\
Trap heating rate: $40^{\circ} \mathrm{C} / \mathrm{s}$ & & \\
\hline
\end{tabular}




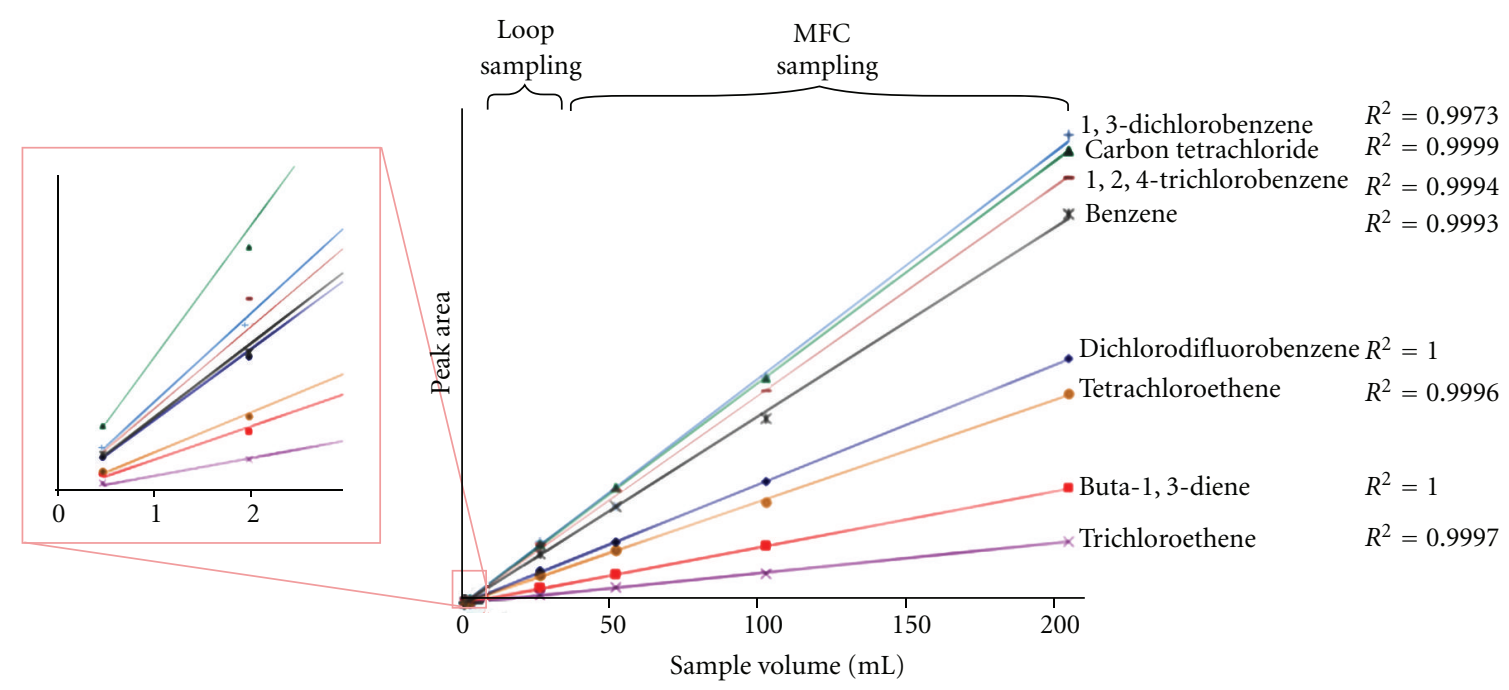

FIGURE 4: Responses for loop sampling (at 0.5 and $2 \mathrm{~mL}$ ) and mass-flow-controlled sampling (at 25, 50, 100 , and $200 \mathrm{~mL}$ ) (CIA-Advantage system, Markes International Ltd) for selected compounds from the TO15 canister standard, showing that a single curve can be fitted to both sets of points (method conditions shown in Table 3).

TABLE 3: Analytical conditions.

\begin{tabular}{|c|c|c|}
\hline TD conditions & GC conditions & MS conditions \\
\hline $\begin{array}{l}\text { Configuration: CIA-Advantage } \\
\text { automated canister analysis system } \\
\text { (Markes International Ltd) } \\
\text { Sampling: } 0.5 \text { and } 2 \mathrm{~mL} \text { samples } \\
\text { collected using } 0.5 \mathrm{~mL} \text { loop; } 25,50 \text {, } \\
100 \text {, and } 200 \mathrm{~mL} \text { sampled with MFC } \\
\text { at } 25 \mathrm{~mL} / \mathrm{min} \text {, with sampling time } \\
\text { varied to produce required volume } \\
\text { Flow path temperature: } 150^{\circ} \mathrm{C} \\
\text { Focusing trap: air toxics analyser } \\
\text { type trap } \\
\text { Trapping temperature: } 25^{\circ} \mathrm{C} \\
\text { Cold trap desorption: } 320^{\circ} \mathrm{C} \text { for } \\
3 \text { min }(5: 1 \text { split) } \\
\text { Trap heating rate: } 40^{\circ} \mathrm{C} / \mathrm{s}\end{array}$ & $\begin{array}{l}\text { Column: } 60 \mathrm{~m} \times 0.32 \mathrm{~mm} \times 1.8 \mu \mathrm{m} \text {, } \\
624 \text { type phase } \\
\text { Oven: } 40^{\circ} \mathrm{C}(5 \mathrm{~min}), 5^{\circ} \mathrm{C} / \mathrm{min} \text { to } \\
230^{\circ} \mathrm{C}(0 \mathrm{~min}) \\
\text { Constant pressure: } 10 \mathrm{psi}\end{array}$ & $\begin{array}{l}\text { Source temperature: } 230^{\circ} \mathrm{C} \\
\text { Quadrupole temperature: } 150^{\circ} \mathrm{C} \\
\text { Transfer line temperature: } 280^{\circ} \mathrm{C} \\
\text { Scan range: } \mathrm{m} / \mathrm{z} 35-300\end{array}$ \\
\hline
\end{tabular}

that these two methods were employed on the same platform. Combined with the low carryover illustrated in Figure 3, this indicates that it should be possible to extend the concentration range of automatic canister air analysis, without fear of system contamination. One benefit of this is that it should allow prescreening of unknown samples in order to optimise parameters for subsequent quantitative analysis.

Further tests were also carried out to evaluate whether or not this new capability could be used to quantify trace- and high-level contaminants in a single, heated canister air sample (Figure 5). While canisters are not the ideal sampling method for higher-boiling contaminants, they are occasionally applied for middle-distillate fuels by heating the canister during subsequent analysis (Note that the use of canisters for higher-boiling contaminants is not covered by standard air monitoring methods and is not normally recommended. Given the static (unpurged) nature of canisters and the challenge of heating an entire canister 


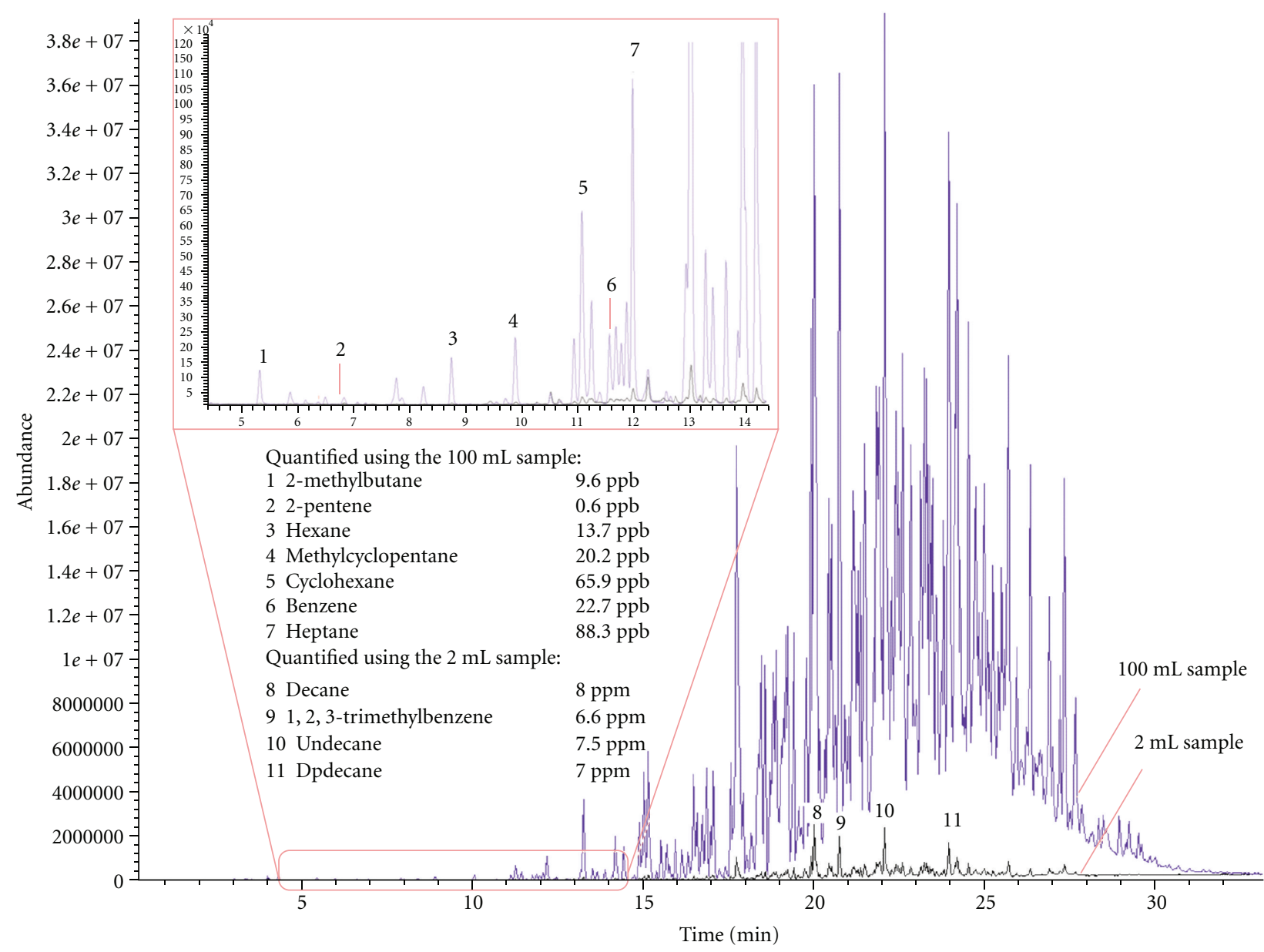

FIGURE 5: High-concentration vapours from a light diesel fraction collected into a canister and analysed using TD-GC/MS (CIA-Advantage system, Markes International Ltd); selected peaks are indicated and their approximate concentrations given. Black trace: $2 \mathrm{~mL}$ sample taken using a gas loop. Blue trace: $100 \mathrm{~mL}$ sample taken using an MFC. Inset: zoomed-in plot, demonstrating the greater sensitivity that results from using MFC sampling (method conditions are shown in Table 4).

TABLE 4: Analytical conditions.

\begin{tabular}{|c|c|c|}
\hline TD conditions & GC conditions & MS conditions \\
\hline $\begin{array}{l}\text { Configuration: CIA-Advantage } \\
\text { automated canister analysis system } \\
\text { (Markes International Ltd) } \\
\text { Sampling: } 2 \mathrm{~mL} \text { (gas sample loop); } \\
100 \mathrm{~mL} \text { (MFC) } \\
\text { Flow path temperature: } 150^{\circ} \mathrm{C} \\
\text { Focusing trap: air toxics analyser } \\
\text { type trap } \\
\text { Trapping temperature: } 25^{\circ} \mathrm{C} \\
\text { Cold trap desorption: } 300^{\circ} \mathrm{C} \text { for } \\
3 \text { min }(7: 1 \text { split) } \\
\text { Trap heating rate: } 40^{\circ} \mathrm{C} / \mathrm{s}\end{array}$ & $\begin{array}{l}\text { Column: } 60 \mathrm{~m} \times 0.32 \mathrm{~mm} \times 1.8 \mu \mathrm{m} \text {, } \\
624 \text { type phase } \\
\text { Oven: } 40^{\circ} \mathrm{C}(5 \mathrm{~min}) 10^{\circ} \mathrm{C} / \mathrm{min} \text { to } \\
260^{\circ} \mathrm{C}(10 \mathrm{~min}) \\
\text { Constant pressure: } 10 \mathrm{psi}\end{array}$ & $\begin{array}{l}\text { Source temperature: } 230^{\circ} \mathrm{C} \\
\text { Quadrupole temperature: } 150^{\circ} \mathrm{C} \\
\text { Transfer line temperature: } 280^{\circ} \mathrm{C} \\
\text { Scan range: } \mathrm{m} / \mathrm{z} 33-350\end{array}$ \\
\hline
\end{tabular}


assembly uniformly, recoveries of higher-boiling analytes invariably remain compromised.). In this case, vapours from a light diesel fraction were analysed first with a low-volume sample $(2 \mathrm{~mL}$, black trace) to quantify high-concentration components and then a larger sample volume $(100 \mathrm{~mL}$, blue trace) to analyse trace-level components.

\subsection{Optimising Analysis of Low-Level Canister Air Samples}

For trace-level target compounds, a large canister $(6 \mathrm{~L})$ is typically used to collect the sample, with a large volume $(1 \mathrm{~L})$ being introduced to the analytical instrument in order to achieve good limits of detection. Furthermore, for trace-level monitoring, it is important that the entire preconcentrated sample is subsequently injected into the GC(MS) for maximum sensitivity. In this case, and as has been reported previously, a narrow-bore focusing trap, offering high linear gas velocity through the trap during the desorption/transfer to the GC column (Figure 1), helps ensure good peak shape for early-eluting compounds $[1,2]$, even under splitless conditions.

Historically, the detection of very low-level compounds in air ( $\ll 1 \mathrm{ppb})$ was possible using sensitive detectors specific for the compounds of interest—for example, flame photometric detection (FPD) provides significantly improved sensitivity for sulfur-containing compounds [14]. Alternatively, the latest TD trapping technology in combination with quadrupole MS in selected ion monitoring (SIM) mode can provide very low detection levels [12] (Figure 6). However, in each of these cases, compound identification relies on a limited number of characteristic ions and stable retention times. In this mode, to improve sensitivity, the vast majority of the spectral data are lost, so full characterisation of the sample is rarely possible in a single analysis.

Time-of-flight (TOF) MS detectors for GC overcome this limitation by monitoring all ions simultaneously across the mass range. This makes them significantly more sensitive than scanning mass spectrometers such as quadrupoles for collection of full spectral information. The sensitivity of TOF technology typically allows SIM-type detection limits to be achieved for very-low-level samples without sacrificing spectral information. Conversely, the sensitivity of TOF can also be harnessed to offer more flexibility for "normal" ambient air monitoring applications. By allowing the collection of smaller sample volumes, method detection limits are not compromised relative to quadrupole mass spectrometers used in full-scan mode. There are several advantages to analysing smaller canister air volumes. Smaller canisters are easier/cheaper to transport, and using smaller volumes allows more repeat analyses to be carried out on a single sample, if required. The use of smaller sample volumes also means that less water is introduced into the system during analysis of humid samples.

Figure 7 shows that Freon 113 (present in the atmosphere at $c a .80 \mathrm{ppt}$ ) can be confidently identified in as little as $10 \mathrm{~mL}$ of semi-rural air using TD-GC-TOF MS. NB Freon 113 provides a useful atmospheric "internal standard," as its lifetime in the atmosphere is about 90 years and it has a uniform distribution over the globe.

Depending on analyte breakthrough volumes during focusing, another approach to improving detection limits may be to use a larger sample size. However, this would require larger canisters for sample collection, with consequent implications for the cost of shipping and storage, and the ease of deploying them in the field.

Recently, there has been a shift in the USA away from canisters, driven by growing interest in compounds that cannot be quantitatively or reliably recovered from canisters under real-world conditions (e.g., naphthalene). Sorbent tubes are now increasingly deployed, as they allow a much wider range of compounds to be analysed [15]. Sorbent tubes also provide greater sample stability as polar compounds are prone to adsorption onto the canister walls [16]. This can be avoided if the correct type of canister is used that is, fully passivated and not electropolished [17]. Studies have also shown that humidification of the sample provides longer holding times for the polar species [17]. 


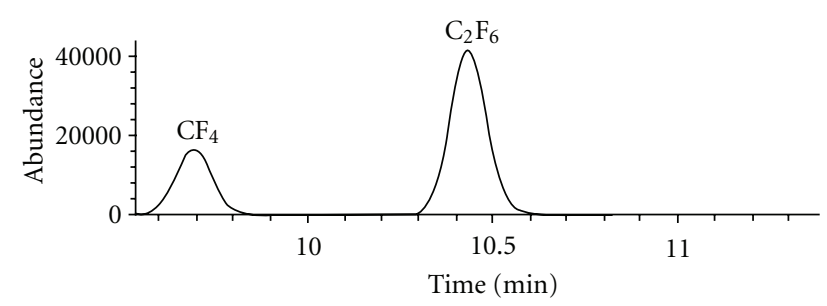

(a)

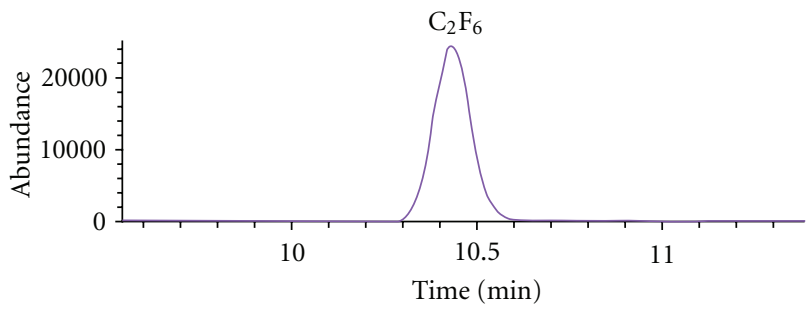

(b)

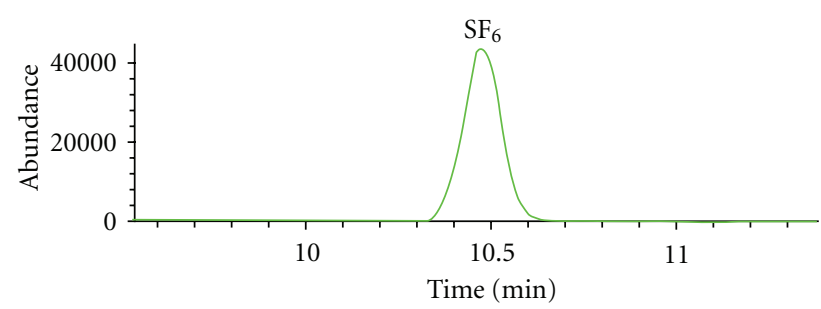

(c)

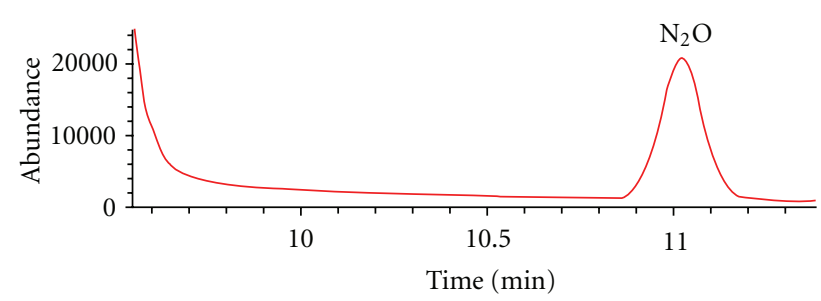

(d)

FIGURE 6: TD-GC/MS (SIM monitoring) chromatograms. Extracted-ion spectra for (a) $\mathrm{CF}_{4}\left(\mathrm{~m} / \mathrm{z}\right.$ 69, $\mathrm{CF}_{3}$ ); (b) $\mathrm{C}_{2} \mathrm{~F}_{6}\left(\mathrm{~m} / \mathrm{z} 119, \mathrm{C}_{2} \mathrm{~F}_{5}\right)$; (c) $\mathrm{SF}_{6}\left(\mathrm{~m} / \mathrm{z} 127, \mathrm{SF}_{5}\right)$; (d) $\mathrm{N}_{2} \mathrm{O}(\mathrm{m} / \mathrm{z} 30$, NO) from a full-scan analysis of $25 \mathrm{~mL}$ of a $100 \mathrm{ppb}$ gas standard [6].

\section{NEW ADVANCES FOR AIR MONITORING USING SORBENT TUBES}

\subsection{Extending the VOC Sampling Range}

Sorbent tubes offer numerous advantages for air monitoring, as they are easy to transport, compatible with a wider range of compounds, and are inherently compatible with a much wider range of air sample volumes. They are also compatible with analytes over a much wider polarity and volatility range. As with focusing traps (e.g., Figure 1), the sorbent combination can be varied according to the compounds of interest, with a series of multiple sorbents being used to retain/release the widest range of compounds.

The choice of sorbent(s) principally depends upon the volatility (specifically the vapour pressure) of the analyte concerned. Appropriate sorbent selection and combination have been discussed elsewhere in greater detail $[1,2]$. However, for information, typical sorbents and their applicable analyte volatility range are shown in Table 6. 


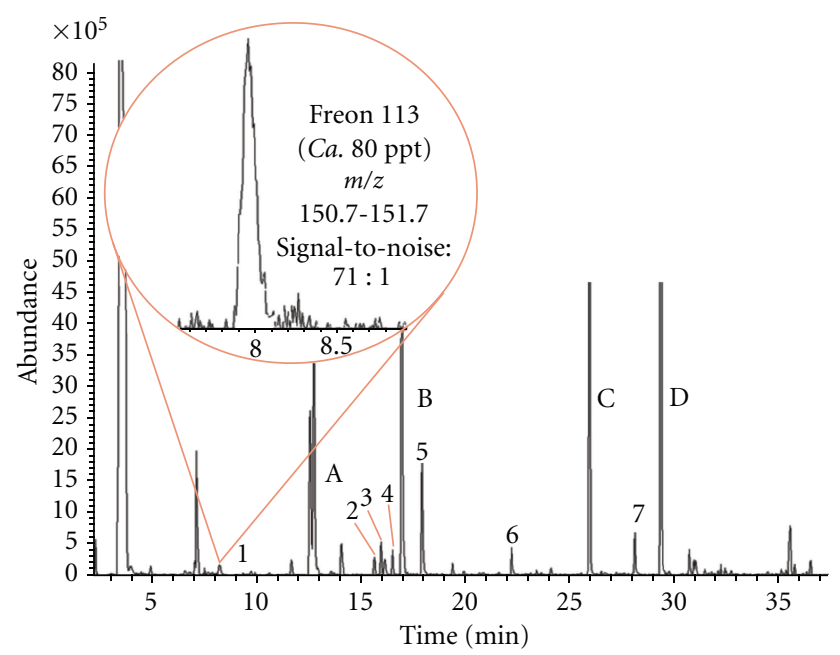
(1) Freon 113
(2) Cyclohexane
(3) 2-methylhexane
(4) Benzene
(5) Heptane
(6) Toluene
(7) Styrene

Internal standards:

(A) Bromochloromethane

(B) 1,3-difluorobenzene

(C) Chlorobenzene- $\mathrm{d}_{5}$

(D) 4-bromofluorobenzene

FIGURE 7: Total ion chromatogram showing splitless analysis of only $10 \mathrm{~mL}$ of semi-rural air using TDGC/TOF MS (TD; CIA-Advantage system, Markes International Ltd, TOF MS; BenchTOF-dx ALMSCO International Ltd, UK). Inset: extracted-ion chromatogram for a characteristic fragment ion of Freon 113 (present in the atmosphere at ca. $80 \mathrm{ppt}$ ). Method conditions are shown in Table 5.

TABLE 5: Analytical conditions.

\begin{tabular}{lll}
\hline TD conditions & GC conditions & TOF MS conditions \\
\hline $\begin{array}{l}\text { Configuration: CIA-Advantage } \\
\text { automated canister analysis system } \\
\text { (Markes International Ltd) }\end{array}$ & & \\
$\begin{array}{l}\text { Sampling: } 10 \mathrm{~mL} / \mathrm{min} \text { for } 1 \mathrm{~min} \\
\text { (MFC) }\end{array}$ & $\begin{array}{l}\text { Column: } 60 \mathrm{~m} \times 0.32 \mathrm{~mm} \times 1.8 \mu \mathrm{m}, \\
\text { Flow path temperature: } 150^{\circ} \mathrm{C}\end{array}$ & $\begin{array}{l}\text { Configuration: BenchTOF-dx } \\
\text { (ALMSCO International Ltd, UK) }\end{array}$ \\
$\begin{array}{l}\text { Cold trap: air toxics analyser type } \\
\text { trap }\end{array}$ & $\begin{array}{l}\text { Oven: } 40^{\circ} \mathrm{C}(5 \mathrm{~min}), 5^{\circ} \mathrm{C} / \mathrm{min} \text { to } \\
\text { Irapping temperature: } 25^{\circ} \mathrm{C}\end{array}$ & $\begin{array}{l}\text { Transfer line temperature: } 240^{\circ} \mathrm{C} \\
\text { Acquisition rate: } 2 \text { data points } / \mathrm{s},\end{array}$ \\
$\begin{array}{l}\text { Cold trap desorption: } 300^{\circ} \mathrm{C} \text { for } \\
\text { Constant pressure: } 10 \mathrm{psi}\end{array}$ & $\begin{array}{l}(5000 \text { spectra/data point) } \\
\text { min (splitless) }\end{array}$ & Mass range: $\mathrm{m} / \mathrm{z} 35-500$ \\
\hline Trap heating rate: $40^{\circ} \mathrm{C} / \mathrm{s}$ & & \\
\hline
\end{tabular}

By choosing an appropriate sorbent combination, a whole suite of compounds can be analysed using only one sorbent tube. One such example is the analysis of 62 air toxic compounds ranging in volatility from freons to hexachloro-1,3-butadiene (Figure 8) collected onto a dual-bed sorbent tube.

\subsection{Grab-Sampling for Sorbent Tubes}

Sorbent tubes are typically used for time-weighted average air monitoring using diffusive (passive) or active sampling methods $[1,2]$. Active sampling traditionally requires some form of calibrated pump-either 
TABLE 6: Popular sorbents and their respective volatility ranges.

\begin{tabular}{lc}
\hline Sorbent name & Volatility range \\
\hline Quartz wool/silica beads & $\mathrm{C}_{30}-\mathrm{C}_{40}$ \\
Tenax TA & $\mathrm{C}_{7}-\mathrm{C}_{30}$ \\
Carbograph 2TD & $\mathrm{C}_{8}-\mathrm{C}_{20}$ \\
Carbograph 1TD & $\mathrm{C}_{5 / 6}-\mathrm{C}_{14}$ \\
Carbograph 5TD & $\mathrm{C}_{3 / 4}-\mathrm{C}_{8}$ \\
Carboxen 1003 & $\mathrm{C}_{2}-\mathrm{C}_{5}$ \\
Carbosieve SIII & $\mathrm{C}_{2}-\mathrm{C}_{5}$ \\
\hline
\end{tabular}

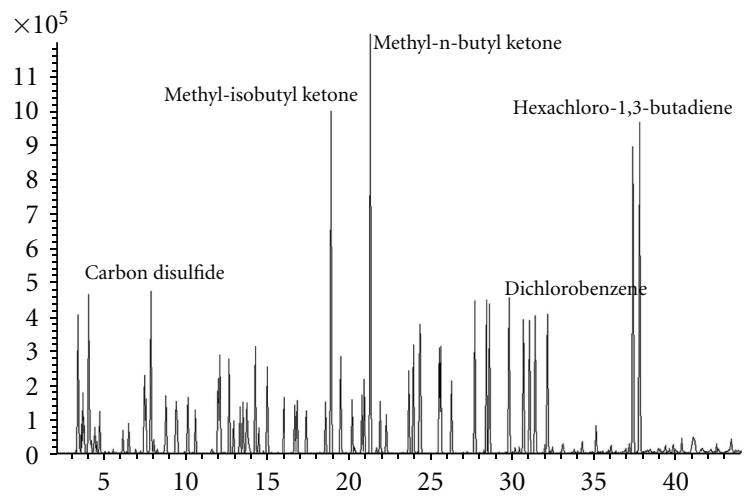

FIGURE 8: Sample equivalent to $1 \mathrm{~L}$ of a $2 \mathrm{ppb}$ standard sampled using dual-bed sorbent tubes and analysed splitless using two-stage thermal desorption (TD-100, Markes International Ltd), method conditions shown in Table 7.

constant-pressure- or constant-flow-type pump. However, simpler active sampling options are now available for "grab sampling" of air/gas volumes up to a few hundred millilitres. Key applications for grab sampling on to sorbent tubes include some industrial emissions (flue gas) measurements, landfill gases [18], and monitoring exhaled breath (e.g., for biological exposure assessment [19]).

Appropriate devices include piston-type pumps or even large gas syringes, which can be coupled to the nonsampling end of tubes, allowing air to be pulled through the sorbent tube as the plunger is withdrawn. Piston pumps are capable of sampling either large sample volumes for trace-level compounds or small sample volumes for high-concentration compounds. The sample size taken depends on the concentration of the compound(s) of interest and the detection method. Figure 9 compares the analysis of two identical laboratory air samples, one "grab sampled" using a piston pump and one collected using a standard constantflow pump both samples were collected on multi-bed sorbent tubes.

\subsection{Benefits of Small Sample Volumes for Sorbent Tubes Using Piston Pump Sampling}

Piston pumps facilitate rapid collection of small volumes of air or gas and offer advantages to many air monitoring applications. For example, low sample volumes reduce the risk of volatile components breaking through the sorbent bed during sampling. They also minimise water retention. Sensitive analytical detectors such as TOF MS can be used to maintain required detection limits.

Figure 10 shows analysis of a small volume of air collected near the exhaust of a diesel car using a multi-bed sorbent tube and a piston pump. Note that the type of sorbent tube used in this case is usually rated for $\mathrm{C} 4 / 5$ to $\mathrm{C} 30$, but compounds as light as propene were quantitatively retained. 
TABLE 7: Sampling and analytical conditions.

\begin{tabular}{lll}
\hline TD conditions & GC conditions & MS conditions \\
\hline $\begin{array}{l}\text { Configuration: TD- } 100 \text { for } \\
\text { automated tube desorption (Markes }\end{array}$ & & \\
$\begin{array}{l}\text { International Ltd) } \\
\text { Flow path temperature: } 150^{\circ} \mathrm{C}\end{array}$ & Column: $60 \mathrm{~m} \times 0.32 \mathrm{~mm} \times 1.8 \mu \mathrm{m}$, & \\
Cold trap: air toxics analyser type & Oven: $40^{\circ} \mathrm{C}(5 \mathrm{~min}), 5^{\circ} \mathrm{C} / \mathrm{min}$ to & Source temperature: $230^{\circ} \mathrm{C}$ \\
trap & $230^{\circ} \mathrm{C}(0 \mathrm{~min})$ & Tradrupole temperature: $150^{\circ} \mathrm{C}$ \\
Trapping temperature: $25^{\circ} \mathrm{C}$ & $\mathrm{Constant}^{\circ}$ pressure: $10 \mathrm{psi}$ & Scan range: $\mathrm{m} / \mathrm{z} 33-350$ \\
Cold trap desorption: $300^{\circ} \mathrm{C}$ for & & \\
3 min $(10: 1$ split) & & \\
Trap heating rate: $40^{\circ} \mathrm{C} / \mathrm{s}$ & & \\
\hline
\end{tabular}

Sampling: $1 \mathrm{~L}$ pumped sampling onto a dual-bed sorbent tube.

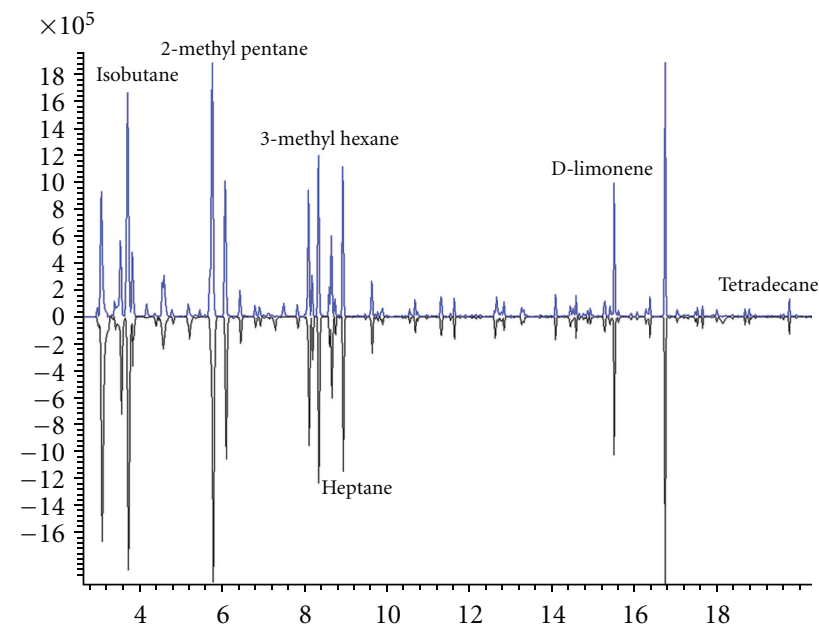

FIGURE 9: Comparison of results from two identical $1 \mathrm{~L}$ laboratory air samples, one collected using a constant-flow pump (black) and the other collected using piston pump (blue), analysed by TD-GC/MS (TD100, Markes International Ltd), method conditions shown in Table 8.

TABLE 8: Sampling and analytical conditions.

\begin{tabular}{|c|c|c|}
\hline TD conditions & GC conditions & MS conditions \\
\hline $\begin{array}{l}\text { Configuration: TD- } 100 \text { for } \\
\text { automated tube desorption (Markes } \\
\text { International Ltd) } \\
\text { Flow path temperature: } 150^{\circ} \mathrm{C} \\
\text { Cold trap: air toxics analyser type } \\
\text { trap } \\
\text { Trapping temperature: } 25^{\circ} \mathrm{C} \\
\text { Cold trap desorption: } 300^{\circ} \mathrm{C} \text { for } \\
3 \text { min }(10: 1 \text { split) } \\
\text { Trap heating rate: } 40^{\circ} \mathrm{C} / \mathrm{s}\end{array}$ & $\begin{array}{l}\text { Column: } 60 \mathrm{~m} \times 0.32 \mathrm{~mm} \times 1.8 \mu \mathrm{m} \text {, } \\
624 \text { type phase } \\
\text { Oven: } 40^{\circ} \mathrm{C}(5 \mathrm{~min}), 5^{\circ} \mathrm{C} / \mathrm{min} \text { to } \\
230^{\circ} \mathrm{C}(0 \mathrm{~min}) \\
\text { Constant pressure: } 10 \mathrm{psi}\end{array}$ & $\begin{array}{l}\text { Source temperature: } 230^{\circ} \mathrm{C} \\
\text { Quadrupole temperature: } 150^{\circ} \mathrm{C} \\
\text { Transfer line temperature: } 280^{\circ} \mathrm{C} \\
\text { Scan range: } \mathrm{m} / \mathrm{z} 33-350\end{array}$ \\
\hline
\end{tabular}




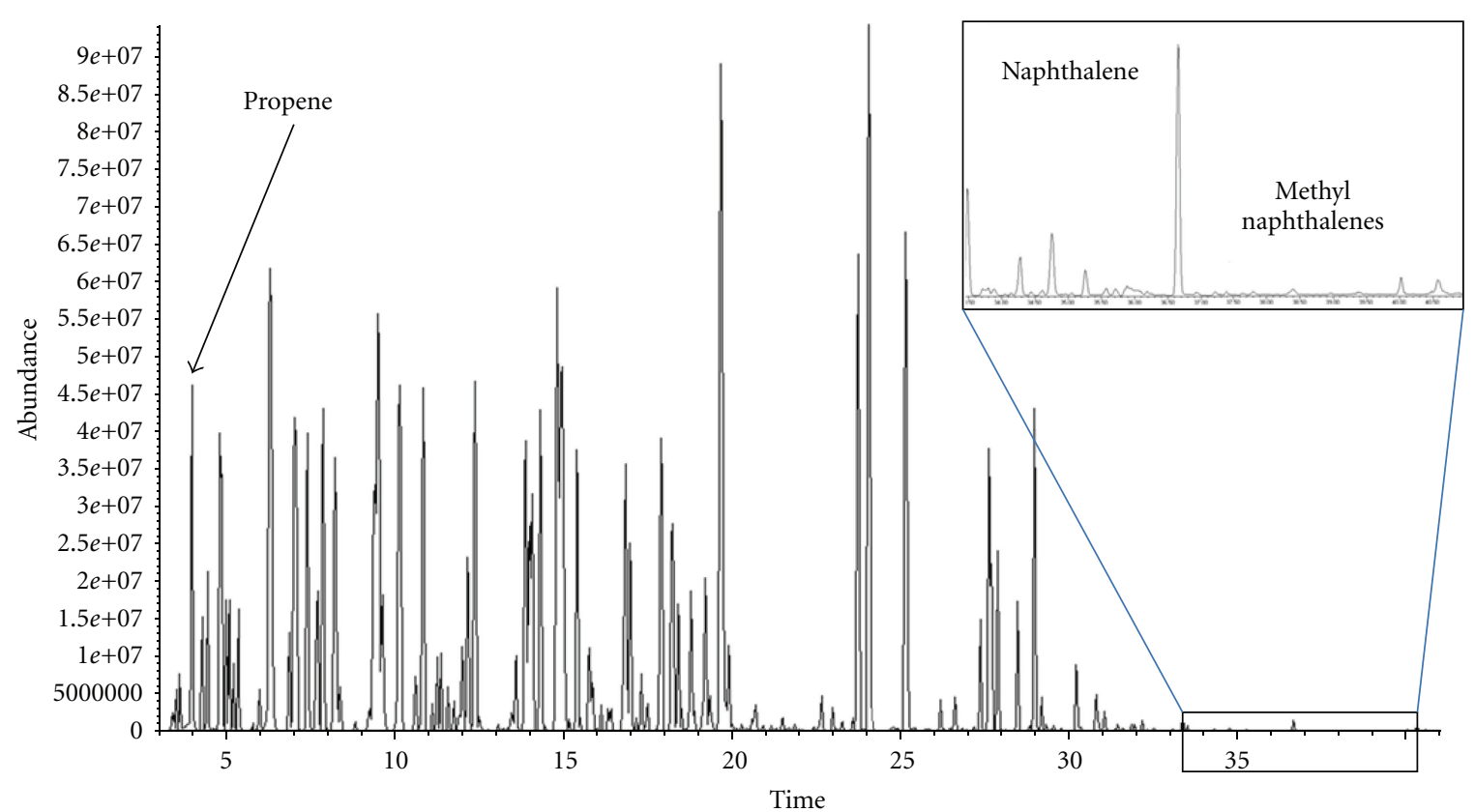

FIGURE 10: Chromatogram of a $50 \mathrm{~mL}$ sample of air taken near a diesel exhaust, analysed using TDGC/TOF MS (TD; TD-100, Markes International Ltd, TOF MS; BenchTOF-dx, ALMSCO International Ltd, UK). Note the quantitative retention of $C_{3}$ hydrocarbons on a tube rated for $C_{4 / 5}$ to $C_{30}$. Method conditions shown in Table 9.

TABLE 9: Sampling and analytical conditions.

\begin{tabular}{lll}
\hline TD conditions & GC conditions & TOF MS conditions \\
\hline $\begin{array}{l}\text { Configuration: TD- } 100 \text { for } \\
\text { automated tube desorption (Markes }\end{array}$ & & \\
$\begin{array}{l}\text { International Ltd) } \\
\text { Flow path temperature: } 180^{\circ} \mathrm{C}\end{array}$ & $\begin{array}{l}\text { Column: } 60 \mathrm{~m} \times 0.32 \mathrm{~mm} \times 1.8 \mu \mathrm{m}, \\
\text { Cold trap: air toxics analyser type }\end{array}$ & $\begin{array}{l}\text { Configuration: BenchTOF-dx } \\
\text { (ALMSCO International Ltd, UK) }\end{array}$ \\
$\begin{array}{l}\text { Oven: } 35^{\circ} \mathrm{C}(5 \mathrm{~min}), 5^{\circ} \mathrm{C} / \mathrm{min} \text { to } \\
\text { trap }\end{array}$ & $\begin{array}{l}\text { Ion source heating: } 240^{\circ} \mathrm{C} \\
\text { Transfer line temperature: } 240^{\circ} \mathrm{C}\end{array}$ \\
$\begin{array}{l}\text { Trapping temperature: } 25^{\circ} \mathrm{C} \\
\text { Cold trap desorption: } 300^{\circ} \mathrm{C} \text { for }\end{array}$ & Constant flow: $1.7 \mathrm{~mL} / \mathrm{min}$ at $35^{\circ} \mathrm{C}$ & $\begin{array}{l}\text { Acquisition rate: } 2 \text { data points } / \mathrm{s}, \\
\text { (5000 spectra/data point) }\end{array}$ \\
Trap heating rate: $40^{\circ} \mathrm{C} / \mathrm{s}$ & & Mass range: $\mathrm{m} / \mathrm{z} 10-500$ \\
\hline
\end{tabular}

Sampling: $50 \mathrm{~mL}$ sample taken onto a dual-bed sorbent tube using one pull of the piston pump set at $50 \mathrm{~mL}$ per pull.

Ambient air monitoring procedures using TD-GC with conventional quadrupole MS technology in scan mode have typically required splitless analysis of sample volumes in the order of $1 \mathrm{~L}$ to reach the detection limits required by the standard methods [3, 20]. However, unless care is taken to selectively eliminate water [21, 22], particularly when monitoring humid atmospheres using tubes containing strong sorbents, such large air sample volumes could lead to the transfer of relatively large quantities of water $(>500 \mu \mathrm{g})$ into the chromatographic system. Potential adverse analytical effects could then include split discrimination, shifting retention times, variable detector response, or masking of high-volatility compounds. A combination of small sample volumes and high-sensitivity TOF MS detection overcomes these issues.

Figure 11 shows the analysis of $500 \mathrm{~mL}$ of a 4 ppb-level standard of volatile hydrocarbons. The sample was analysed using TD-GC with three different detection techniques-a quadrupole mass spectrometer in full-scan and SIM mode, and a TOF mass spectrometer. The split flow was recollected 


\begin{tabular}{|cc|}
\hline Detection method & S/N \\
\hline Full scan (quad) & $15: 1$ \\
\hline SIM (quad) & $200: 1$ \\
\hline BenchTOF & $1500: 1$ \\
\hline
\end{tabular}

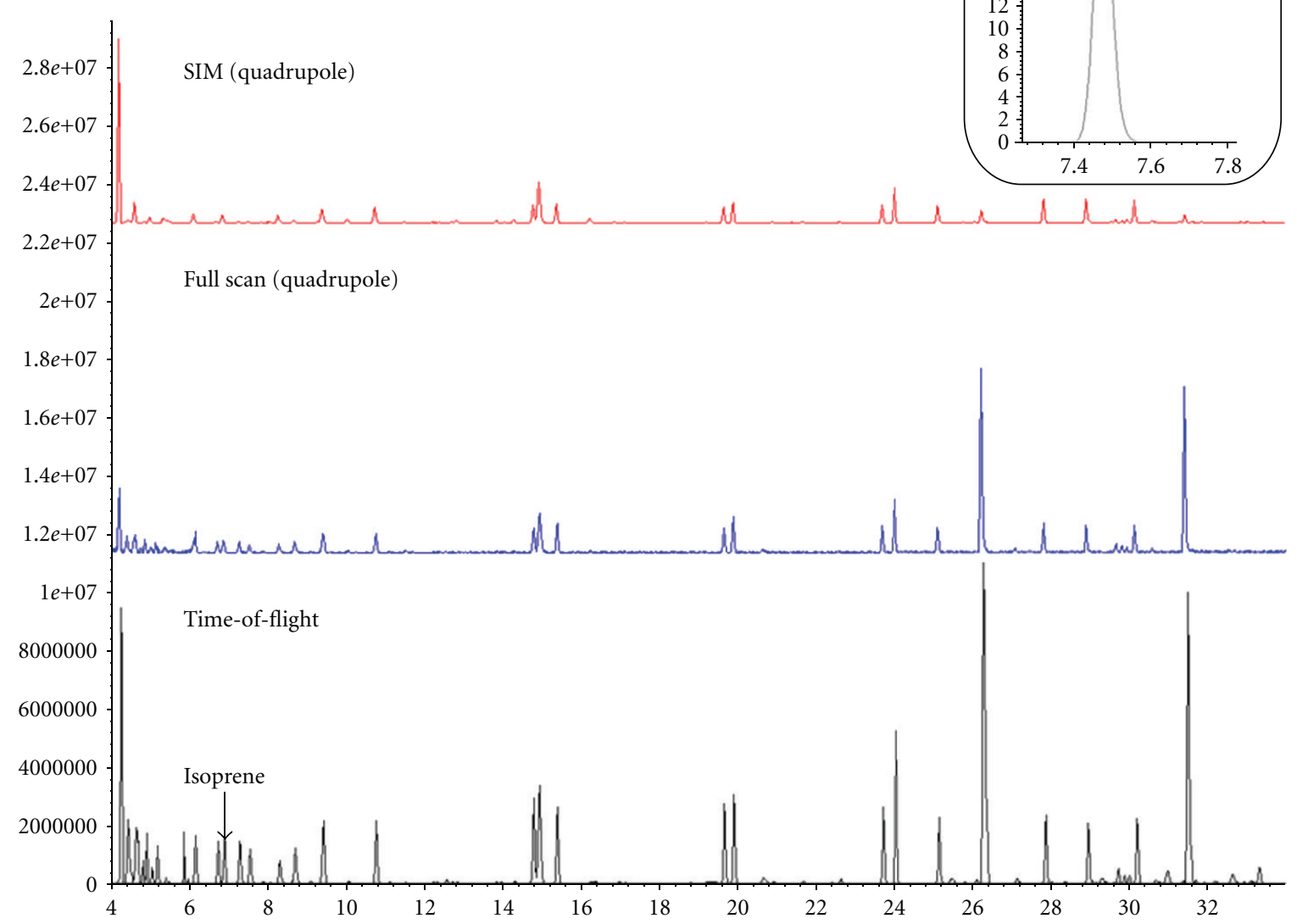

FIGURE 11: $500 \mathrm{~mL}$ of a $4 \mathrm{ppb}$ level hydrocarbon standard collected on a multi-bed tube using a piston pump and analysed by TD-GC/MS (TD-100, Markes International Ltd), using a quadrupole mass spectrometer (full scan, blue; SIM, red) and a TOF mass spectrometer (black-BenchTOF-dx ALMSCO International Ltd, UK). Table inset shows the root-mean-square (RMS) signal-to-noise ratio (S/N) for isoprene using the ion at $\mathrm{m} / \mathrm{z} 67$. The inset shows extracted-ion $\mathrm{m} / \mathrm{z} 67$ for $260 \mathrm{pg}$ of isoprene on column, showing excellent peak shape and a signal-to-noise ratio for TOF MS implying a detection limit for isoprene of $\ll 10$ ppt under the conditions used. Method conditions are shown in Table 10.

onto a clean sorbent tube during each run to facilitate repeat analysis of the same sample by each of the detection methods. Three different detection techniques were chosen to show the enhancement in sensitivity that occurs when using TOF detection. Published specifications of quadrupole analysers have signal-tonoise ratios for octafluoronaphthalene (OFN) between 160:1-450:1 for full-scan mode, and however, this depends on the mass range that was chosen when the signal-to-noise check was performed. A general signalto-noise value for quadrupoles tends to be $400: 1$ for a mass range 50 to $400 \mathrm{~m} / \mathrm{z}$. Just as quadrupoles differ in sensitivity so do TOF instruments and published specifications for OFN signal to noise range from 10:1 to $800: 1$. The instrument used in this paper has a published specification for OFN signal to noise of $800: 1$ over $1-1000 \mathrm{~m} / \mathrm{z}$. 
TABLE 10: Sampling and analytical conditions.

\begin{tabular}{lll}
\hline TD conditions & GC conditions & MS conditions \\
\hline & & $\begin{array}{l}\text { Quadrupole } M S \text { conditions } \\
\text { Source temperature: } 230^{\circ} \mathrm{C}\end{array}$ \\
& & Quadrupole temperature: $150^{\circ} \mathrm{C}$ \\
Configuration: TD- 100 for & & Transfer line temperature: $280^{\circ} \mathrm{C}$ \\
automated tube desorption (Markes & & Scan range: $\mathrm{m} / \mathrm{z} 25-300$ \\
International Ltd) & Column: $60 \mathrm{~m} \times 0.32 \mathrm{~mm} \times 1.8 \mu \mathrm{m}$, & SIM ions: $29,43,53,57,67,78,82$, \\
Flow path temperature: $150^{\circ} \mathrm{C}$ & 624 type phase & 91,105, and 120 \\
Cold trap: Air Toxics Analyser type & Oven: $35^{\circ} \mathrm{C}(5 \mathrm{~min}) 5^{\circ} \mathrm{C} / \mathrm{min}$ to & TOF MS conditions \\
trap & $230^{\circ} \mathrm{C}(0 \mathrm{~min})$ & Configuration: BenchTOF-dx \\
Trapping temperature: $25^{\circ} \mathrm{C}$ & Constant flow: $1.7 \mathrm{~mL} / \mathrm{min}$ at $35^{\circ} \mathrm{C}$ & (ALMSCO International Ltd, UK) \\
Cold trap desorption: $300^{\circ} \mathrm{C}$ for & & Ion source heating: $240^{\circ} \mathrm{C}$ \\
3 min $(10: 1$ split) & & Transfer line temperature: $240^{\circ} \mathrm{C}$ \\
Trap heating rate: $40^{\circ} \mathrm{C} / \mathrm{s}$ & & Acquisition rate: 2 data points $/ \mathrm{s}$ \\
& & (5000 spectra $/$ data point) \\
& & Mass range: $\mathrm{m} / \mathrm{z} 25-500$ \\
\hline
\end{tabular}

Sampling: $500 \mathrm{~mL}$ of hydrocarbon standard taken onto a multi-bed sorbent tube using five pulls of the piston pump set at $100 \mathrm{~mL}$ volume per pull* . * Note that setting the split ratio at 10:1 enabled $90 \%$ of the sample to be recollected for repeat analysis. The order of analyses was as follows: quad scan (100\% level), quad SIM (90\% level), then TOF ( $81 \%$ level).

RMS signal-to-noise ratios $(\mathrm{S} / \mathrm{N})$ for each of the detection methods are shown for isoprene using the ion at $\mathrm{m} / \mathrm{z}$ 67. The full-scan quadrupole method is near the detection limit, assuming at lower limit of $3: 1 \mathrm{~S} / \mathrm{N}$, while both the SIM quadrupole and the TOF methods provide S/N ratios above the limit of detection. However, using the quadrupole in SIM mode means that spectral information is lost, compromising analysis of unknowns and increasing the possibility of false positives. With the TOF detector, full spectral information is retained while detection limits remain at or better than those obtained from a quadrupole in SIM mode.

In a further example, a $200 \mathrm{~mL}$ sample of outdoor air from a predominantly rural environment was taken using a piston pump-Figure 12 shows extracted ion $\mathrm{m} / \mathrm{z} 117$ for carbon tetrachloride (present in the atmosphere at $c a .100 \mathrm{ppt}$ ) for each of the detection methods, along with respective $\mathrm{S} / \mathrm{N}$ ratios. Like Freon 113 , carbon tetrachloride is also often used as an atmospheric "internal standard", as its residence time in the atmosphere is $c a$. 50 years and it has a uniform distribution across the globe.

\section{CONCLUDING REMARKS}

These examples have shown how recent advances in air monitoring technology have extended the range and robustness of GC-based analytical procedures for air samples collected using either canisters or sorbent tubes. Some of the potential applications and advantages that have been explored here include automated screening of uncharacterised canister samples, reliable detection of very-low-concentration species and technologies to facilitate transition from canisters to sorbent tubes, with the employment of simple grab sampling devices.

With the advancement of air sampling techniques and technology, excellent linearity and detection methods are available to ensure that laboratory inaccuracies are minimised. The greatest area for inaccuracy when making ambient air measurements now lies within the sample collection itself. This paper has discussed the two main sampling types for VOC collection, canister sampling and absorbent tube sampling, and it is important to ensure that when taking the sample the correct collection method is employed.

These new technologies lend themselves to sampling smaller air volumes onto sorbent tubes, which can dispel user worries about breakthrough volumes and humidity effects. Taking small sample volumes 


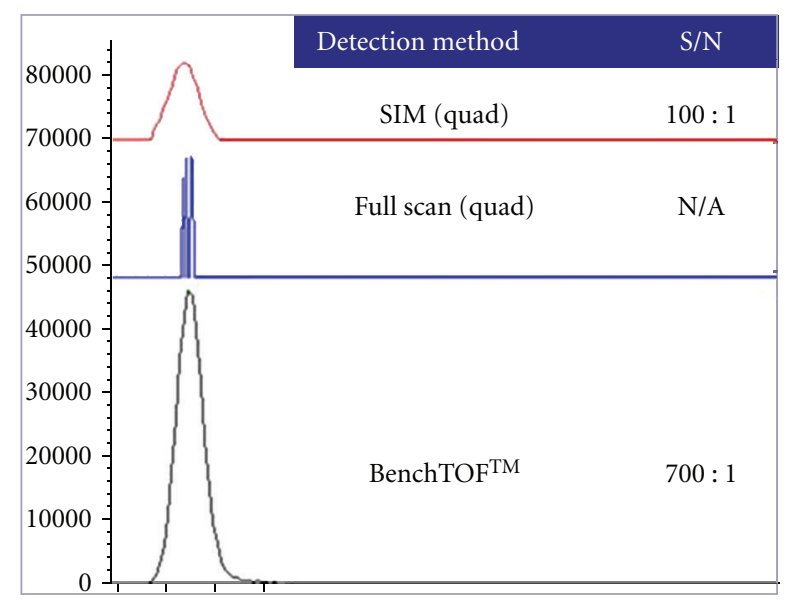

FIGURE 12: Extracted-ion 117 for carbon tetrachloride from a $200 \mathrm{~mL}$ sample of semi-rural ambient air, analysed by TD-GC/MS (TD-100, Markes International Ltd), using a quadrupole mass spectrometer (full scan, blue; SIM, red) and a TOF mass spectrometer (black-BenchTOF-dx ALMSCO International Ltd, UK). Signal-to-noise ratios are shown for each detection method. Note that quadrupole in full scan did not detect this compound. Method conditions are shown in Table 11.

TABLE 11: Sampling and analytical conditions.

\begin{tabular}{|c|c|c|}
\hline TD conditions & GC conditions & MS conditions \\
\hline $\begin{array}{l}\text { Configuration: TD- } 100 \text { for } \\
\text { automated tube desorption (Markes } \\
\text { International Ltd) } \\
\text { Flow path temperature: } 150^{\circ} \mathrm{C} \\
\text { Cold trap: air toxics analyser type } \\
\text { trap } \\
\text { Trapping temperature: } 25^{\circ} \mathrm{C} \\
\text { Cold trap desorption: } 300^{\circ} \mathrm{C} \text { for } \\
3 \text { min }(5: 1 \text { split) } \\
\text { Trap heating rate: } 40^{\circ} \mathrm{C} / \mathrm{s}\end{array}$ & $\begin{array}{l}\text { Column: } 60 \mathrm{~m} \times 0.32 \mathrm{~mm} \times 1.8 \mu \mathrm{m} \text {, } \\
624 \text { type phase } \\
\text { Oven: } 35^{\circ} \mathrm{C}(5 \mathrm{~min}), 5^{\circ} \mathrm{C} / \mathrm{min} \text { to } \\
230^{\circ} \mathrm{C}(0 \mathrm{~min}) \\
\text { Constant flow: } 1.7 \mathrm{~mL} / \mathrm{min} \text { at } 35^{\circ} \mathrm{C}\end{array}$ & $\begin{array}{l}\text { Quadrupole MS conditions } \\
\text { Source temperature: } 230^{\circ} \mathrm{C} \\
\text { Quadrupole temperature: } 150^{\circ} \mathrm{C} \\
\text { Transfer line temperature: } 280^{\circ} \mathrm{C} \\
\text { Scan range: } \mathrm{m} / \mathrm{z} 20-300 \\
\text { SIM ions: } 56,57,58,67,78,91,93 \text {, } \\
\text { 106, } 117 \text {, and } 151 \\
\text { TOF } M S \text { conditions } \\
\text { Configuration: BenchTOF-dx } \\
\text { (ALMSCO International Ltd, UK) } \\
\text { Ion source heating: } 240^{\circ} \mathrm{C} \\
\text { Transfer line temperature: } 240^{\circ} \mathrm{C} \\
\text { Acquisition rate: } 2 \text { data points } / \mathrm{s} \\
\text { (5000 spectra/data point) } \\
\text { Mass range: } \mathrm{m} / \mathrm{z} 25-500\end{array}$ \\
\hline
\end{tabular}

Sampling: $200 \mathrm{~mL}$ of semi-rural air taken onto a multi-bed sorbent tube using two pulls of the piston pump set at $100 \mathrm{~mL}$ volume per pull.

and combining this with powerful detection techniques, such as time-of-flight mass spectrometry, allows detection of trace compounds to be achieved either at the same level or at much lower limits of detection when compared to less sensitive detection techniques.

However, more work is required to identify the limits of new time-of-flight mass spectrometer technologies when used in combination with TD-GC systems for real-world air monitoring.

\section{ACKNOWLEDGMENT}

Freon is the registered trademark for several different chlorofluorocarbons or CFCs-trademarked by Dupont. The authors do not have a direct financial relation with the commercial identity. 


\section{REFERENCES}

[1] E. Woolfenden, "Sorbent-based sampling methods for volatile and semi-volatile organic compounds in air-part 1: sorbent-based air monitoring options," Journal of Chromatography A, vol. 1217, no. 16, pp. 2674-2684, 2010.

[2] E. Woolfenden, "Sorbent-based sampling methods for volatile and semi-volatile organic compounds in air-part 2. Sorbent selection and other aspects of optimizing air monitoring methods," Journal of Chromatography A, vol. 1217, no. 16, pp. 2685-2694, 2010.

[3] US EPA Method TO-15, The determination of volatile organic compounds (VOCs) in air collected in SUMMA®) passivated canisters and analyzed by gas chromatography/mass spectrometry.

[4] Y. Liu, M. Shao, L. Fu, S. Lu, L. Zeng, and D. Tang, "Source profiles of volatile organic compounds (VOCs) measured in China_part I," Atmospheric Environment, vol. 42, no. 25, pp. 6247-6260, 2008.

[5] ASTM D5466-95 Standard test method for determination of volatile organic chemicals in atmospheres (Canister sampling methodology).

[6] P. Ciccioli, "VOC in European countries: sampling, determination and monitoring strategies," in Proceedings of the Workshop on VOC Assessment and Evaluation, H. T. Bloemen and J. Burn, Eds., pp. 122-143, RIVM, Amersfoort, The Netherlands, 1993.

[7] X. L. Cao and N. C. Hewitt, "The sampling and analysis of volatile organic compounds in the atmosphere," in Reactive Hydrocarbons in the Atmosphere, N. C. Hewitt, Ed., pp. 199-157, Academic Press, San Diego, Calif, USA, 1999.

[8] EN ISO 16017 Air quality, Sampling and analysis of volatile organic compounds in ambient air, indoor air and workplace air by sorbent tube/thermal desorption/capillary gas chromatography. Part 1: Pumped sampling and Part 2: Diffusive sampling.

[9] US EPA publication: Technical assistance document for sampling and analysis of ozone precursors. EPA/600-R98/161.

[10] K. H. Kim, Y. Choi, E. Jeon, and Y. Sunwoo, "Characterization of malodorous sulfur compounds in landfill gas," Atmospheric Environment, vol. 39, no. 6, pp. 1103-1112, 2005.

[11] K. P. Song, J.-S. Han, M.-D. Lee et al., "A study of quality assurance/quality control between institutions for reduced sulfur compounds in the ambient air using cryofocusing thermal desorber with GC/PFPD," Korean Journal of Odor Research and Engineering, vol. 6, pp. 33-39, 2007.

[12] D. Wevill, "The use of a thermal desorption system as a cryogen-free method for the monitoring of trace greenhouse gases in air," Labmate, vol. 34, no. 7, 2009.

[13] I. A. Bowles and L. Burt, "Method for the determination of air-phase petroleum hydrocarbons (APH)," Massachusetts Department of Environmental Protection, 2009.

[14] K. H. Kim, D. W. Ju, and S. W. Joo, “The evaluation of recovery rate associated with the use of thermal desorption systems for the analysis of atmospheric reduced sulfur compounds (RSC) using the GC/PFPD method," Talanta, vol. 67, no. 5, pp. 955-959, 2005.

[15] H. C. Hayes, D. J. Benton, S. Grewal, and N. Khan, "Evaluation of sorbent methodology for petroleum impacted site investigations," in Proceedings of the Air and Waste Management Association conference on Vapor Intrusion, 2007.

[16] R. W. Coutant, "Theoretical Evaluation of Stability of Volatile Organic Chemicals and Polar Volatile Organic Chemicals in Canisters," EPA Contract 68-DO-0007, Environmental Protection Agency, 1993.

[17] T. J. Kelly, P. J. Callahan, J. Pleil, and G. F. Evans, "Method development and field measurements for polar volatile organic compounds in ambient air," Environmental Science and Technology, vol. 27, no. 6, pp. 1146$1153,1993$.

[18] UK Environment Agency Publication, Guidance for monitoring trace components in landfill gas, Ref: LFTGN 04, 2004.

[19] D. Dyne, J. Cocker, and H. K. Wilson, “A novel device for capturing breath samples for solvent analysis,” Science of the Total Environment, vol. 199, no. 1-2, pp. 83-89, 1997.

[20] US EPA Method TO-17, Determination of volatile organic compounds in ambient air using active sampling on to sorbent tubes. 
[21] J. Gawlowski, T. Gierczak, E. Pietruszynska, M. Gawrys, and J. Niedzielski, "Dry purge for the removal of water from the solid sorbents used to sample volatile organic compounds from the atmospheric air," Analyst, vol. 125, no. 11, pp. 2112-2117, 2000.

[22] M. Gawryś, P. Fastyn, J. Gawłowski, T. Gierczak, and J. Niedzielski, "Prevention of water vapour adsorption by carbon molecular sieves in sampling humid gases," Journal of Chromatography A, vol. 933, no. 1-2, pp. 107-116, 2001.

This article should be cited as follows:

Nicola Watson, Stephen Davies, and David Wevill, "Air Monitoring: New Advances in Sampling and Detection,” TheScientificWorldJOURNAL, vol. 11, pp. 2582-2598, 2011. 

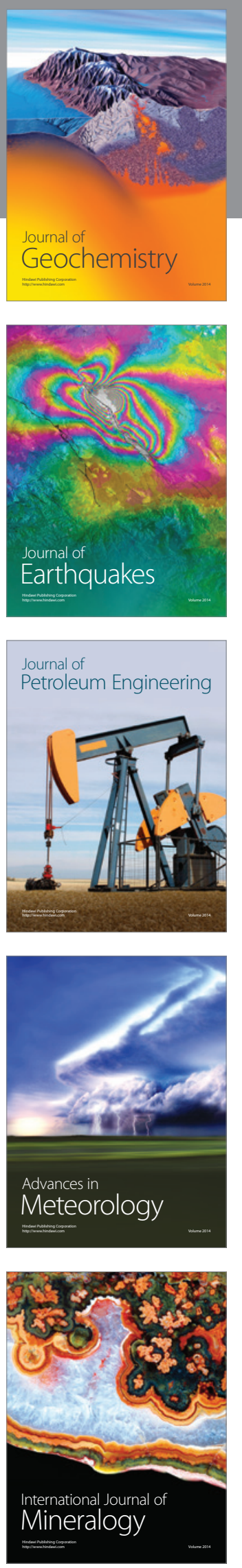
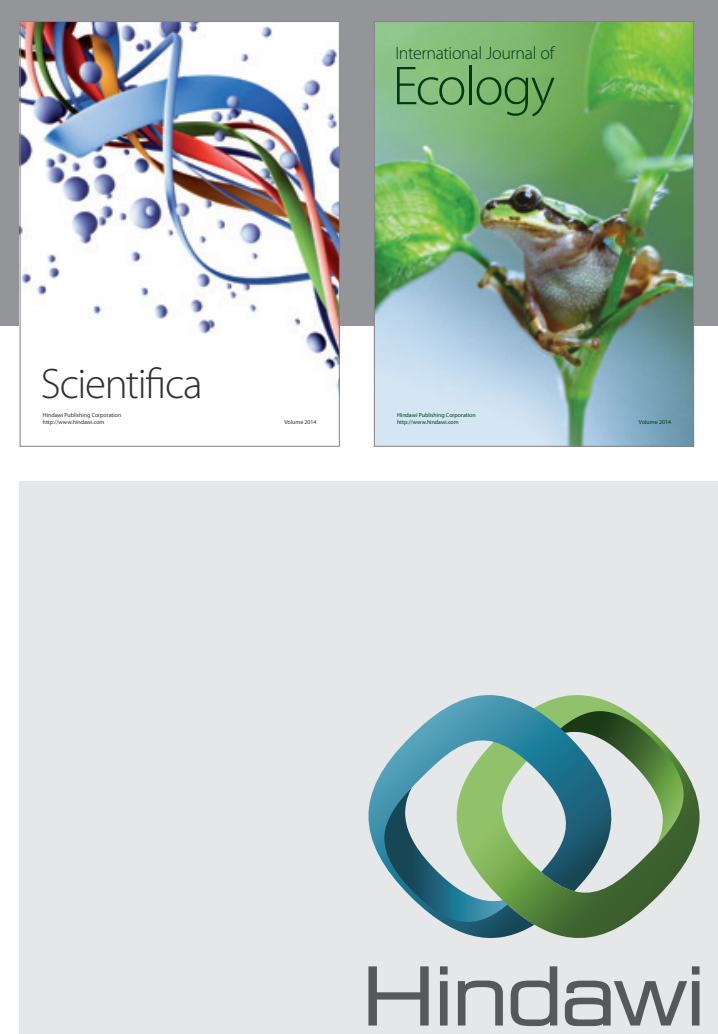

Submit your manuscripts at http://www.hindawi.com
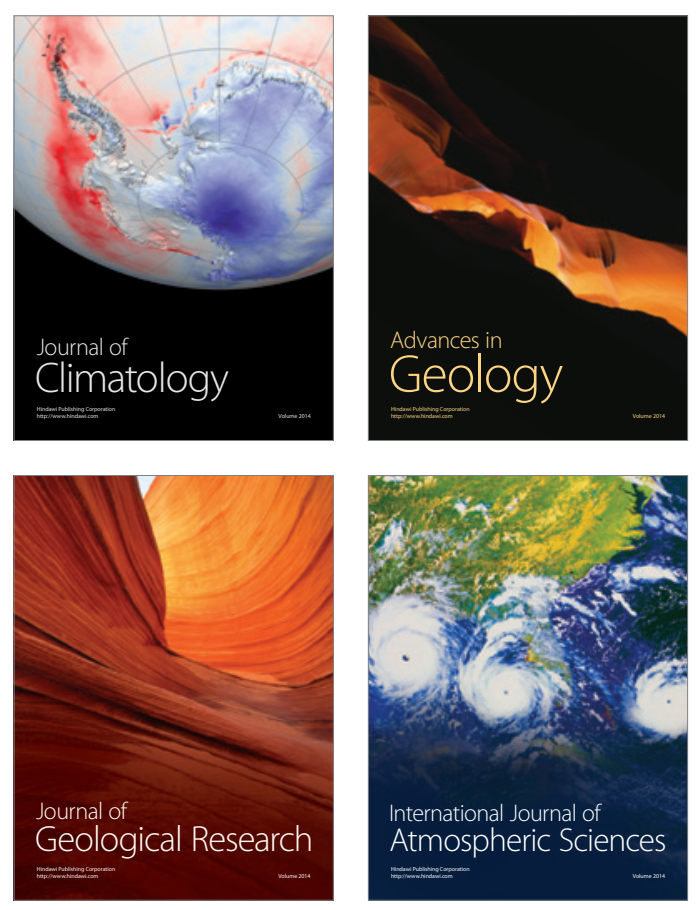
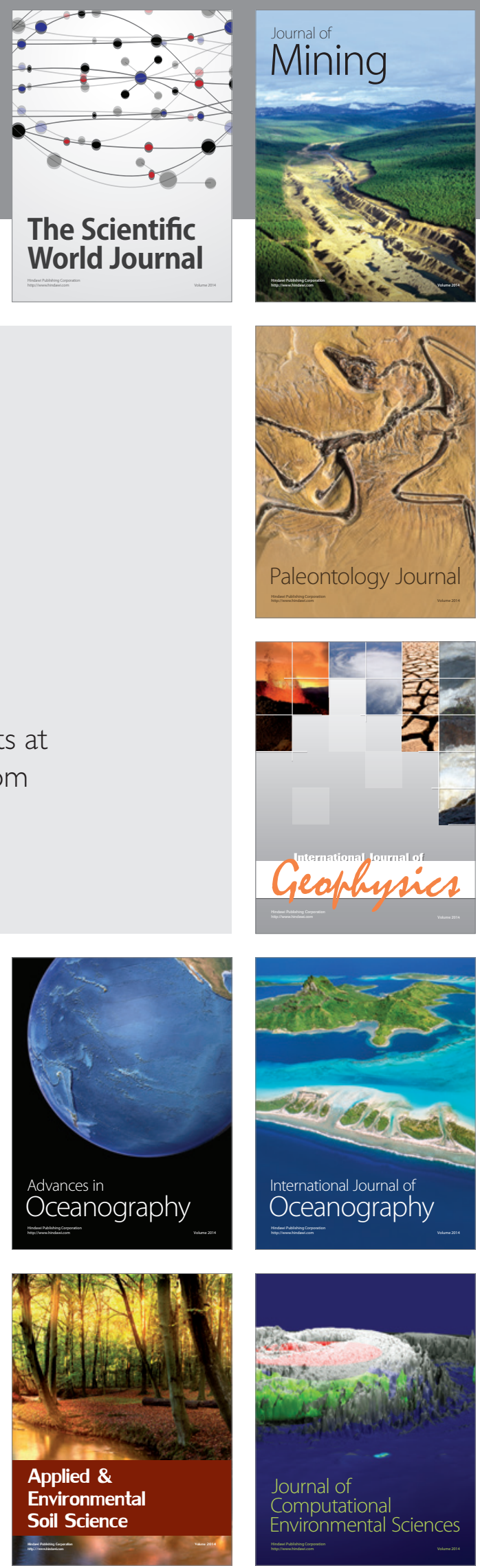